\title{
Hold beina på bakken
}

I en artikkel i dette nummer av Tidsskriftet viser Haug og medarbeidere at ambulansehelikopteret fra Brønnøysund kun gjennomførte svært få oppdrag vinterstid $\mathrm{i}$ tre innlandskommuner (1). Om helsepolitikere trodde at ambulansehelikopteret kunne løfte pasienter fra disse stedene forbi Mosjøen og ut til sykehus med døgnkirurgi, har forfatterne vist at dette ikke går i vinterhalvåret. Helgelandssykehuset Mosjøen er viktig for å behandle eller stabilisere disse pasientene. Som forfatterne skriver, er dette ikke enestående for denne regionen. Store innlandsområder i Norge med langt flere innbyggere kan i mørke og snøvær heller ikke regne med ambulansehelikopteret. Forklaringen er i hovedsak at de aktuelle ambulansehelikoptrene ikke kan fly uten å se landskapet og i kaldt vær ikke kan fly gjennom skyene uten at rotorbladene iser. Hvordan kan dette forbedres? Instrumentinnflyvning til forberedte helikopterlandingsplasser i Norge vil kreve en ekstra pilot og oppvarmede rotorblad. Da kan oppdrag til de forberedte landingsplassene gjennomføres under nesten alle værforhold. Slike helikoptre er imidlertid kostbare og oftest større. Dette medfører for eksempel at helikopteret ikke alltid kan lande tett ved trafikkulykker.

Funnene til Haug og medarbeidere er imidlertid ikke så dramatiske som man først kan få inntrykk av. Siden om lag 13500 av de 16600 innbyggerne bor i Mosjøen med flyplass og ambulanseflytilgang rett ved, må vi anta at behovet for ambulansehelikopter særlig gjelder de om lag 3000 innbyggerne i kommunene Grane og Hattfjelldal og en relativt beskjeden vintertrafikk på E6 på ca. 1200 biler per døgn.

I tillegg til at den manglende dekningen i vinterhalvåret berører et relativt beskjedent antall innbyggere, er det klart at det for en rekke tilstander foreligger adekvate transportmuligheter allerede. Ved behov for perkutan koronar intervensjon må pasientene, som i Bodø, fraktes med ambulansefly til enten Tromsø eller Trondheim. Disse pasientenes luftambulansebehov dekkes altså av ambulanseflyet. Det gjelder også alle andre pasienter som ikke kan behandles i Sandnessjøen eller Mo i Rana. Mosjøen flyplass har høy regularitet. Resten av pasientene kan bruke pålitelig helårlig bilambulanse fra Mosjøen til sykehusene i Mo i Rana eller Sandnessjøen, som tar henholdsvis 80 og 65 minutter. Veien til Sandnessjøen er planlagt forbedret bl.a. med tunnel, og reisetiden kan sannsynligvis da forkortes til omtrent 45 minutter. Til denne transporten er det ikke behov for helikopter.

Det er derfor mye som tyder på at bilambulansene er viktigere for å opprettholde sikker tjeneste til befolkningen enn en utbygging av ambulansehelikoptrene. Helseforetakenes nasjonale luftambulansetjeneste fraråder at ambulansehelikoptrene brukes som påskudd til å bygge ned bilambulansene. Nord i Nordland, der over $70 \%$ av befolkningen bor i kommuner som i praksis aldri benytter seg av helikopterets ambulansetjeneste, er bilambulansetjenesten og kommunehelsetjenestens akuttmedisinske kompetanse viktig (2). En ny rapport fra Helse- og omsorgsdepartementet foreslår at «legevaktslegen kjøres av ambulansearbeider i en utstyrt og uniformert bil i store legevaktdistrikter. En slik løsning fremmer legevaktslegens mulighet til å delta i akuttsituasjoner, fremmer legens tilgjengelighet i helseradionettet og øker sikkerheten ved legevaktsbesøk» (3). La oss igjen ta situasjonen sør i Nordland som eksempel: Der er det legevaktlege og ambulansebil både i Trofors og Hattfjelldal.
Transporten til Mosjøen der det er anestesilege, indremedisiner og kirurg i døgnvakt, tar henholdsvis en halvtime og én time. Ambulansebil med anestesilege eller anestesisykepleier fra Mosjøen vil kunne bringe tilsvarende kompetanse som ambulansehelikopteret ut til pasienten i innkommende ambulansebil og konkurrere på tid. Det forventes et lavt antall nødvendige utrykninger. Siden det er bestemt at kun planlagte kirurgiske inngrep skal gjøres ved Helgelandssykehuset Mosjøen, vil anestesilegen sjelden komme i samtidighetskonflikter med viktigere arbeid på sykehuset. En slik bilutrykningstjeneste vil ha kortere responstid og er dessuten sikrere. Risikoaspektet kommer man dessverre ikke utenom. Antall helikopterulykker i USA avtok i mange år, som i Norge, men økte igjen fra 1,7 per 100000 flytimer i 1997 til 4,8 i 2004. Nå diskuteres det igjen om flere pasienter kunne fraktes i bilambulanse (4). I Stavanger-området, som riktignok er tettere befolket, er det interessant å merke seg at man ikke kunne vise forskjell i reddede leveår om legen rykket ut i bilambulanse eller i ambulansehelikopter (5).

Bilambulansers og legevaktlegers akuttmedisinske potensial kommer dessverre lett $\mathrm{i}$ bakgrunnen av det spektakulære ambulansehelikopteret. Om helsepersonell og helsepolitikere i større grad fokuserte på det medisinske innholdet, ville man dels se at størstedelen av helikopteroppdragene er transport uten avansert behandling $(2,6)$, dels at kommuneleger og lokalt tilpassede bilambulanseløsninger kunne tatt hånd om de fleste oppdragene. Dette viser Haug og medarbeideres artikkel med all mulig tydelighet.

\section{Erik Waage Nielsen}

erikwn@fagmed.uit.no

Erik Waage Nielsen, f. 1956, er overlege ved Anestesiavdelingen, Nordlands sykehuset, Bodø, og professor ved Universitetet i Tromsø. Han har lang erfaring fra helikopter-og flyambulansetjenesten i Bodø, Banak og Brønnøysund.

Oppgitte interessekonflikter: Ingen

\section{Litteratur}

1. Haug B, Åvall A, Monsen S-A. Luftambulansens pålitelighet - en undersøkelse i tre kommuner på Helgeland. Tidsskr Nor Legeforen 2009; 129: 1089-93.

2. Ulvik A, Rannestad BS, Carlsen AW et al. Redningshelikoptertjenesten i Bodø avansert akuttmedisin eller alternativ transport? Tidsskr Nor Lægeforen 2002; 122: $25-9$.

3. Pedersen AR, Lindheim NJ, Tvete $P$ et al. En helhetlig gjennomgang av de prehospitale tjenestene med hovedvekt på AMK-sentralene og ambulansetjenesten. Rapport fra arbeidsgruppe nedsatt av Helse- og omsorgsdepartementet mars 2009. www.helse-nord.no/viktige-dokumenter/category22130.html (12.5. 2009).

4. Greene J. Rising helicopter crash deaths spur debate over proper use of air transport. Ann Emerg Med 2009. 53: 15-7A.

5. Lossius HM, Soreide E, Hotvedt R et al. Prehospital advanced life support provided by specially trained physicians: is there a benefit in terms of life years gained? Acta Anaesthesiol Scand 2002; 46: 771-8.

6. Gisvold SE. Helicopter emergency medical service with specially trained physicians - does it make a difference? Acta Anaesthesiol Scand 2002; 46: $757-8$. 